Marlan Hutahaean

Master of Administrative Science and Department of Public Administration, Faculty of Social and Political Sciences, Universitas HKBP Nommensen Medan, Indonesia

Email: marlan.hutahaean@uhn.ac.id

Submitted: 22 November 2019, Revised: 12 December 2019, Accepted: 14 February 2020

\section{Marlan Hutahaean}

is an associate professor in the Department of Public Administration, Faculty of Social and Political Sciences, Universitas HKBP Nommensen Medan. He obtained his doctorate in public administration from the Faculty of Social and Political Sciences, Universitas Gadjah Mada, Yogyakarta, in 2013. Since 2018, he has served as head of the Master of Administrative Science Study Program, Postgraduate Program at Universitas HKBP Nommensen, Medan. Marlan teaches several courses, including Introduction to Public Administration, Public Policy Analysis, Public Policy Implementation, Strategic Leadership and Change, Local Public Administration, and Public Service. He has worked on various scientific studies and publications relating to the fields of public policy, bureaucracy, public organization, governance and decentralization.
Policy \& Governance Review ISSN 2580-4820

Vol. 4, Issue 2, pp. 87-98 DOI: https://doi.org/10.30589/pgr. v4i2.274

\title{
Implications of the Decentralization Policy on Poverty Reduction in Indonesia
}

\begin{abstract}
This paper aims to analyze the implications of decentralization policies that are linked to poverty reduction in Indonesia. The focus of the study is the decentralization policy as regulated in Law No. 22/1999, which was amended twice through Law No. 32/2004 and Law No. 23/ 2014 concerning local government. In addition, it also discussed Law No. 25/ 1999 concerning financial relations in the central-regional government. Using qualitative methods with a policy/program analysis approach and secondary data, this study found that decentralization policies do not link directly to poverty reduction. Out of 34 provincial regions, only 8 provincial regions have achieved a human development index (HDI) above the national average, while having a poverty rate below the national average. In contrast, there are 13 provincial regions that reached HDI below the national average and at the same time have poverty levels above the national average. Based on these findings, this study recommends, first, that local governments evaluate and direct various programs that lead to HDI improvement and poverty reduction. Second, that they synchronize poverty reduction programs in the regions with the same programs from the central government and international programs in the regions.
\end{abstract}

\section{Keywords:}

public policy; decentralization; poverty reduction; human development index; income raise

\section{Introduction}

This paper aims to analyze the implications of decentralization policies that are linked to poverty reduction in Indonesia. The focus of the study is the decentralization policy as regulated in Law No. 22/1999, which was amended twice through Law No. 32/2004 and Law No. 23/2014 concerning regional government. In addition, it also discussed Law No. 25/1999 concerning financial relations in the central-regional government. The two policies cannot be separated, because the transfer of functions from the center to the regions must be followed by funding. This is known as follow money functions. The argument to choose a 
decentralized policy is that through this policy, it is hoped that regional development will proceed quickly, which is marked by regional economic growth and poverty reduction. The arguments built are (1) a decentralized policy that does not link significantly to poverty reduction in regency/ municipality areas; (2) there is an assumption that poverty reduction is the duty and responsibility of the central government, so that the regions do not explicitly make programs that link directly to poverty reduction; (3) if economic growth occurs in regency/municipality areas, it does not automatically reduce poverty. Furthermore, to prove the successful implementation of decentralization policy, it will be explained by looking at the link between decentralization policy and the achievement of the human development index (HDI) with poverty levels.

Decentralized systems are those in which central entities play a lesser role in any or all of these dimensions (Schneider, 2003) . Decentralization (local autonomy) has emerged as a new paradigm in development policy and administration since the 1970s. Growing attention to decentralization is not only related to the failure of centralized planning and the popularity of growth with equity strategies, but also to the realization that development is a complex and uncertain process that cannot be easily controlled and planned from the center. For this reason, the pioneers of decentralization put forward a long line of reasons and arguments about the importance of decentralization in planning and administrating in third-world countries, especially in accelerating regional economic development and growth. The World Bank also encourages donor recipient countries to implement decentralization (Amal \& Pratikno, 1996).

Decentralization policy should also be related to the emergence of policy innovations. Policy innovation means there are policies that are anti-mainstream. The aim of policy innovation is to accelerate development and to improve the welfare of the community. Successful policy experiments are eventually emulated. Experiments benefit not just the innovating government but also potential imitators, and so local governments have an incentive to freeride off their neighbors. Alternatively, a central government should take this learning externality into account when deciding whether to consider a policy experiment (Stumpf, 2002).

In Indonesia, the decentralization policy is stipulated through Law No. 22 of 1999 concerning regional government, which was implemented in January 1, 2001. This law regulates the clear division of authority between the central and regional governments. There are at least 6 (six) central powers that are stipulated through this law, namely monetary and fiscal fields, foreign policy, justice, defense and security, religion and national macro planning. While the authority of the regions is in the fields of public works, health, education, investment, environment, land, social, transportation, agriculture, cooperatives and labor. Afterwards, through Law No. 32/2004, the authority of districts/municipalities is divided into compulsory and optional affairs. Obligatory affairs are related to planning and control of development, planning, utilization, and supervision of spatial planning, the implementation of public order and public peace, handling the health sector, organizing education, overcoming social problems, employment services, facilitating the development of cooperatives, small and medium enterprises, environmental control life, land services, population services and civil registration, public and government administrative services, investment administration services, other basic services, and other mandatory functions mandated by laws and regulations. Meanwhile, other matters relating to district/municipal governmental affairs that are optional include government affairs that actually exist and have the potential to improve the welfare of the community in accordance with the conditions, uniqueness, and superior potential of the region concerned. 
The problem is that at first glance, we see cities/municipalities have been given broad authority by the center, but if we examine more deeply, that is not the case. Moreover, the approach used in the distribution of authority is that the central government first regulated its authority, while the remaining power was given to the regions. This shows that the central government is still dominant in controlling development.

Furthermore, district/municipality authority has also been reduced recently, namely by transferring it to provincial authority. Some examples of functions that were previously district/municipality affairs but later became provincial affairs include forestry and senior secondary and/or vocational education. Senior high schools and/or vocational schools that have been managed by the regency/city government are the province's affairs as stipulated in Law No. 23 of 2014 concerning regional government.

On the other hand, the distribution of authority is also not accompanied by financial surrender. This shows that what actually happened was the transfer or shift of functions or tasks as stated in Article 11 paragraph 2, without any budget submission to the district/municipality. In other words, the funds used to finance the implementation of the overall tasks of the field are still very dependent on the central government. Therefore, it is not surprising if we see that after Law No. 22/1999 was effectively implemented on 1 January 2001, the district's/municipality's local budgeting (APBD) remained dependent on the central government through balance funds, which then turned into regional transfers, such as the General Allocation Fund (DAU). We just look at the sources of regional finance; it is not experiencing a significant change from before. PAD or local revenue contribution to the total APBD or expenditure is still very small.

The research results of the Faculty of Social and Political Sciences, Gadjah Mada University in collaboration with the Ministry of Home Affairs in 1992 showed the small contribution of PAD to the regional budget. Of the 292 (two hundred ninety two) districts/municipalities that existed at the time, there were 122 city districts whose PAD contribution was between the district budget and $0.00-10.00 \%$. Furthermore, as many as 86 districts/municipalities contributed between 10.10 and $20.00 \%$; 43 regencies/cities contributed between 20.10 and $30.00 \% ; 22$ regencies/cities contributed between 30.10 and $40.00 \% ; 17$ regencies/cities contributed between 40.10 and $50.00 \%$; and only 2 districts/municipalities have a PAD contribution to the regional budget that is above $50 \%$.

The decentralization has been running for about 18 (eighteen) years, and still the district/ municipality budget is highly dependent on the central government. The difference is that in addition to regional transfers, such as the General Allocation Fund, the central government has issued a new policy in the form of village funds. The existence of village funds will certainly reduce the burden on the regency budget in financing village development. The average contribution of the central government to the regional budget is in the range of $70 \%$. In 2011, for example, the average PAD contribution was only $17.8 \%$, while fiscal transfers were $72.9 \%$, with an average DAU of 50.4\% (Lisna, Sinaga, Firdaus, \& Sutomo, 2013). Furthermore, Ahmad (1998), as quoted by (Jia, Guo, \& Zhang, 2014), states that district governments are less fiscally independent. Therefore, over the past decade, most developing and transitional countries have either embarked upon or stated their intention to embark upon some type of fiscal decentralization initiative (Vazquez \& Mcnab, 2003) .

Considering that financially only a few regions are able to carry out delegated administrative functions, due to the wealth of natural resources, such as Aceh, East Kalimantan, Riau, Papua and West Papua, as well as for income tax revenue sharing, such as Surabaya and Jakarta, 
the majority of regions must be able to increase PAD. This is in line with one of the principles of fiscal decentralization, "Local governmental units should have revenues available to meet adequately their obligations" (UNDP, 1999).

In terms of poverty levels, even though during the Five Years Term for Development (Pelita) VI during the New Order and until the current Reform Order, Indonesia was able to reduce the number of people living on the poverty line, the results achieved were not yet satisfactory. Indeed, as a percentage, the number has decreased and is at a lift of $9.2 \%$ of the total population. However, when compared to other developing countries in Asia, Indonesia is one of the countries with the poorest population, both in absolute and relative terms. This means that it requires more serious and conceptual handling. Not only that, success in poverty reduction also depends on the ability to manage various resources and environmental conditions. This is in line with what (Jones, 2002) said, "In many developing countries, social and economic development, including alleviation of poverty, depend heavily on the proper use and effective management of environmental resources and related ecosystems."

(Kuncoro, 2004) identified the causes of poverty in economic terms, namely:

1. At a micro level, poverty arises because of inequality in resource ownership, which results in an unequal distribution of income. The poor only have limited resources and the quality is low.

2. Poverty arises due to differences in the quality of human resources. Low-quality human resources equals low productivity, which in turn equals low wages. The low quality of human resources is due to lack of education, disadvantaged fortune, discrimination or because of heredity.

3. Poverty arises due to differences in access to capital. Ragnar Nurkse, a well-known development economist in 1953, further said that a poor country is poor because it is poor. This view came to be known as the vicious circle of poverty theory. Low income will result in low saving ability. Furthermore, low saving ability will result in low capital ownership, which will ultimately result in low productivity. This will continue as a cycle [Moeljarto in (Hutahaean, 2006)]

Bhagwati (1988) said that, with the amelioration of poverty as the target, the policy instruments designed to achieve that target can be divided into two main classes: (i) the indirect route, i.e., the use of resources to accelerate growth and thereby the impact on the incomes and hence the living standards of the poor; and (ii) the direct route, i.e., the public provision of minimum-needs-oriented education, housing, nutritional supplements and health. and transfers to finance private expenditures on these and other components of the living standards of the poor.

Meanwhile, (Adams, 2002) said there were 6 (six) things that caused various ideas or instruments of public policy to fail in reducing poverty. These six things are:

(1) The decline of public advocates and the demise of epistemic community;

(2) The perception of poverty as an avoidable externality of modernity for which economic solution should be paramount;

(3) The failure of government;

(4) The data maze;

(5) The loss of visibility and class basis of poverty; and

(6) The emergence of new and better ideas.

On the other hand, although regional government expenditure does not automatically reduce poverty, it is usually expected that the budget for the education and health sector can reduce poverty (Bird \& Rodriguez, 1999)

The question is, what are the parameters of poverty? In the Indonesian context, poverty 
indicators often refer to formulations issued by the Statistics Indonesia (BPS). BPS sets a poverty line limit through spending the rupiah value, which is equivalent to 2100 calories per capita per day plus the rupiah value, which is only enough to consume the most essential non-food commodities. This means that BPS uses two kinds of approaches: the basic needs approach and the head count index. The first approach is an approach that is often used. In the BPS method, poverty is conceptualized as the inability to meet basic needs, while the head count index is a measure that uses absolute poverty. The number of poor people is the number of people who are in a boundary called the poverty line limit, which is the rupiah value of minimum food and nonfood needs. Thus, the poverty line consists of two components: the food poverty line and the nonfoodline poverty line.

Another very famous poverty line in Indonesia is what was created by Sajogyo. From years of studies, he measured poverty lines using standard rice prices. Sajogyo defines poverty as the level of consumption per capita a year which is the same as rice. In other words, the Sajogyo poverty line is a rupiah value equivalent to $20 \mathrm{~kg}$ of rice for rural areas and $30 \mathrm{~kg}$ of rice for urban areas. This limit changes again to $320 \mathrm{~kg}$ for rural areas and $480 \mathrm{~kg}$ for urban areas.

On the other hand, the World Bank calculates the poverty line which is called the absolute poverty line. In this way, the measure of poverty is carried out through the use of issued consumption, which is converted into US \$ PPP (purchasing power parity), and not using the official US \$ exchange rate (Heltberg, 2009). The aim is the use of PPP so that levels of poverty can be compared fairly between countries. The benefit is to determine the direction of using financial resources owned and to assess the progress of the distribution of financial resources, including assessing the progress of poverty reduction. Conversion using the PPP figure will obtain information about the amount of rupiah that is consumed to buy goods or services; the same amount can be purchased in America for US \$1. The calculation of this conversion number is based on price and quantity in each country whose data is obtained through a survey, which is usually done once in five years. The World Bank generally uses two measures: a) US \$1 PPP per capita per day; (b) US $\$ 2$ PPP per capita per day. The measure was later changed to US \$1.25 PPP and US \$2 PPP per capita per day.

Finally, in the 1990s, the United Nations Development Program (UNDP), a poverty measurement model called the human development index (HDI) was introduced. The UNDP approach is relatively more comprehensive when compared to the approach taken by the World Bank, because the measure of poverty is not only about consumption ability or economic dimensions, but also the dimensions of education (literacy rates and education completed) and health (life expectancy).

Based on the various explanations above, the research question in this paper is: What are the implications of the decentralization policy for poverty reduction in Indonesia?

\section{Methods}

The method is a method used by researchers to collect and analyze data to test or answer research questions that have been formulated previously. The choice of method is closely related to the type of data and objectives desired by the researcher and the scope of the study. This research wants to see the link between decentralization policy and poverty reduction, which uses secondary data obtained through various documents such as books, journals, previous research results, websites, and regional success stories that have succeeded in reducing poverty. Related above, this study uses a qualitative method. (Cresswell, 2009), states that qualitative research methods are "methods to explore and 
understand the meaning-by individuals or groups of people-ascribed to social problems or humanity." Furthermore, (Denzin \& Lincoln, 2005) define qualitative research method as a way to "study things in their natural settings, attempting to make sense of, or interpret, phenomena in terms of the meanings people bring to them."

The data collected in this study was analyzed with descriptive analysis. By this technique, it will be illustrated throughout the data or facts will be obtained from the field by applying the following procedure:

a. Using descriptive analysis to develop categories that are relevant to the purpose of research.

b. Interpreting the results of descriptive analysis according to the data and theories accordingly.

Specifically, the data analysis is done by the following steps:

1. The various data is grouped according to the main objectives to be achieved, especially the emergence of decentralization policies in Indonesia.

2. Furthermore, poverty in Indonesia is explained, especially in regency areas.

3. The third part will explain the implications of the decentralization policy for poverty reduction. This implication is measured from the human development index (HDI) and poverty in the regency/municipality. However, because there are 514 regencies/ municipalities, so that the data can be presented easier, the comparison of the two is accumulated.

4. Finally, drawing conclusions of the link between decentralization policies and poverty reduction is done through HDI and poverty. High HDI (above the national average) and followed by poverty (below the national average) indicate that there is a tendency that decentralization policies are functioning well. Furthermore, if HDI is high (above the national average), but the poverty rate is also high (above the national average), then there are problems with the program related to poverty reduction. Programs that are formulated related to poverty reduction directly are still very minimal. Then, if HDI is low (below the national average), but the poverty rate is low, it means that the formulation and implementation of the program is less directed at improving education, health and community income. Conversely, if HDI is low (below the national average) with high poverty (above the national average), then there is a problem in implementing decentralization policies.

\section{Results and Discussion}

Performance is defined as the level of achievement of results. We can see this through the achievement of goals and objectives, or at least through the indicators that have been prepared before a policy is formulated. In general, the main objective of the decentralization policy formulated in 1999 was to free the central government from unnecessary burdens in handling domestic affairs, so that it had the opportunity to study, understand, respond to global trends and take advantage of these trends. In addition, the central government would be better able to concentrate on formulating national macro policies. Conversely, through a decentralization policy, regions would experience a significant empowerment process. Their ability of initiative and creativity would be encouraged, so that the ability to overcome various domestic problems was stronger, especially in accelerating development in order to reduce poverty.

It is often mentioned that the objectives of the decentralization policy concern two main things: the redistribution of authority in the field of government and the economic sector (fiscal decentralization). The principle of its implementation is directed to accelerate the realization of community welfare through service improvement and empowerment, and to be able to increase competitiveness by paying 
attention to the principles of democracy, equity, justice, specificity, regional potential and diversity (Rudzali \& Sudarlan, 2016). However, to measure the performance of the implementation of decentralization policies, the indicators used are the following: 1. each regency/municipality is able to arrange and manage its household; 2 . all government affairs that have been submitted to the regency/municipality have been implemented; 3. the set of regulations in the form of government regulations regarding the transfer of functions have been reviewed and harmonized with the nuances of development; 4. PAD that increases and supports in a balanced manner as needed and if possible accelerates regional economic growth; 5. the realization of the mechanism of technical guidance by the technical minister, general guidance by the interior minister, operational guidance by the province without friction and overlap between coaching.

Referring to point 4 (four) above, the actual success or performance of the implementation of the decentralization policy is very dependent on whether PAD is increasing and regional economic growth is accelerating. Economic growth in the region is expected to reduce poverty. This is also one of the goals to be achieved from the decentralization policy as mentioned earlier.

In fact, after approximately 18 (eighteen) years of the decentralization policy being implemented, it seems that it has not yet yielded maximum results, especially if measured from the indicators in point 4 above. As mentioned earlier, the hope of increasing PAD's contribution to spur regional economic growth in the context of accelerating regional development has not been successful. Especially if it is associated with an increase in the human development index and reducing poverty. Indeed there are regions that have succeeded in reducing poverty, but the number is very small when compared to the number of 514 districts/municipalities in Indonesia. Some regions have succeeded in reducing poverty rates, such as Jembrana in Bali, Bantaeng Regency in South Sulawesi, Morowali Regency in Central Sulawesi and Kulonprogo district in Yogyakarta.

Jembrana is one of the districts that was previously a poor district in the province of Bali. However, because the local government sided with the poor, their welfare improved. In 2010, the number of poor people was 21,300 people or around $8.11 \%$ of the population, which in 2017 was successfully reduced to around 14,780 people or around $5.38 \%$ of the population. This data shows that in 7 (seven) years, there was a poverty reduction of $2.73 \%$. Although the poverty rate is relatively small when compared to the national average, this poverty rate is still above the average poverty rate in Bali Province at $4.25 \%$ in 2017. Meanwhile, the district's HDI in 2017 is at 70, 72, and it increased to 71.65 in 2018. In 2017, this regency ranked 155 of 514 districts/ municipalities in Indonesia. That is, in terms of HDI, this district is good enough.

Meanwhile, Bantaeng regency, in the 5 (five) years of Nurdin Abdullah's leadership, was able to reduce poverty from the previous $12.12 \%$ to $7.5 \%$ (Haboddin, 2017). However, this poverty rate increased slightly in 2018 to $9.23 \%$. In contrast, the HDI of Bantaeng district has increased in the last 5 (five) years. HDI of Bantaeng district was 65.77 in 2014; 66.20 in 2015; 66.59 in 2016; 67.27 in 2017; and 67.76 in 2018. In 2017, HDI Bantaeng ranks 291 out of 524 districts/cities in Indonesia. Nationally, this position is in the middle to lower position, which of course still needs to be improved again.

The head of the Morowali District, Anwar Hafid, who ruled for two periods from 20082013 and 2013-2018, has succeeded in reducing poverty from $28.27 \%$ in 2007 to $15.13 \%$ in 2016 , and then poverty reduced again to 70.41 in 2017, and finally to 71.14 in 2018. In 2017, this district ranked 165 out of 514 districts/cities in Indonesia. Thus, within a period of 9 (nine) years 
under his leadership, the poverty rate fell by $13.14 \%$. Likewise, the human development index continued to increase from 69.12 in 2015 to 69.69 in 2016. This increase brought the position of this regency to second after the city of Palu, which has HDI 79.73 (Hafid, 2018).

Likewise in Kulonprogo district, the regent who has served for 2 (two) periods has succeeded in improving the welfare of his people. Various policies have been carried out in order to reduce poverty, such as the obligation for the state civil apparatus to buy rice produced by farmers from the district at least $10 \mathrm{~kg}$ a month. Of course, this policy will increase the income of farmers, because farmers have certainty in price and buyers. Another policy is to require schools and National Civilian Apparatus to wear batik products from the district once a week. This will certainly increase the income of batik craftsmen. Not only that, but the people of Kulonprogo who had made batik to Yogya, because batik craftsmen were limited; after this policy, batik artisans flourished. Even those who had made batik in Yogyakarta eventually returned to their districts. Although still small, this district has succeeded in reducing poverty from $23.62 \%$ in 2011 to $20.03 \%$ in 2017 . This is a $3.59 \%$ reduction in poverty over a period of 6 years. Meanwhile, HDI data in Kulonprogo district in the last 5 (five years) showed an increase. HDI in 2014 was 70.68 ; in 2015 , it was 71.52 ; in 2016 , it was 72.38; in 2017, it was 73.23, and in 2018, it amounted to 73.76. HDI figures indicate that the Kulonprogo district is ranked below number 100 , which is sequence number 98 .

However, there are even more districts that have not been successful in reducing poverty rates. The newly formed districts show that this region received a red report card in terms of improving community welfare. From 7 provinces, 164 regencies, and 34 municipalities resulting from the division during the 1999-2009 period, only two regions received a total score above 60 out of 100 . The two regions were Banjarbaru
City, South Kalimantan, with a total value of 64.61, and Cimahi City, West Java, with a value of 60.43. Many regions get a minimum score for certain categories. North Toraja Regency (South Sulawesi), Tulang Bawang Barat (Lampung), Yalimo (Papua), Aru Islands (Maluku), North Gorontalo (Gorontalo), Meranti Islands (Riau), Morotai (North Maluku), Mesuji (Lampung), Sigi (Central Sulawesi), and Southwest Maluku (Maluku) got zero for competitiveness indicators. Deiyai Regency (Papua) gets a blank value for an indicator of people's welfare. The districts of Puncak Jaya and Paniai in Papua received blank scores for indicators of community welfare, governance, and competitiveness (KPPOD, 2011).

When measured by HDI and poverty rates, the districts/municipalities resulting from the division will also show the same results: HDI is relatively low and the poverty rate is relatively high. West Tulang Bawang Regency in the last 5 (five) years has increased HDI, but it is still in the middle to lower order. HDI for 2014 amounted to 62.46; in 2015, it was 63.01; in 2016, it was 63.77; in 2017, it was 64.58; and in 2018, it was 65.30. Meanwhile, the poverty rate in 2018 was 21,930 people or $8.10 \%$ of the population. Furthermore, Meranti Islands district in the last 5 (five) years of having HDI in a row was 62.91 in 2014; 63.25 in 2015; 63.90 in 2016; 64.70 in 2017; and 65.23 in 2018. Meanwhile, the poverty rate of the district, which was established in 2009, has indeed decreased from $43.80 \%$ in 2009 to around $28 \%$ in 2018. Although this decline is quite good, the poverty rate is still high.

In the Aru Islands district, Maluku, HDI in the last 5 (five) years in a row was 59.91 in 2014; 60.50 in 2015; 61.32 in 2016; 62.13 in 2017; and 63.12 in 2018 . Meanwhile, the poverty rate in 2018 was still quite high, which was 25,680 people or $27.12 \%$ of the population. Meanwhile, in Paniai district, HDI in the last 5 (five) years in a row was 53.93 in 2014; 54.20 in 2015; 54.34 in 2016; 54.91 in 2017; and 55.83 in 2018. In 2017, the HDI of 
this district ranks number 498. In 2018, even that position did not change much. Meanwhile, the district poverty rate is still very high, namely in 2018 amounting to 64,460 people or $37.35 \%$ of the population (Statistics Indonesia, 2018).

Furthermore, although the decentralization policy focuses on districts/cities, because some of the authorities that were previously located in districts/cities were then transferred to provincial authorities, to make it easier to find out the link or influence of decentralization policies on poverty, HDI data and poverty levels were presented at the provincial level. As mentioned earlier, it is easier to see the link between decentralization policies and poverty reduction through HDI and poverty. High HDI (above the national average), followed by low poverty (below the national average) shows that there is a tendency that decentralization policies are functioning well. Conversely, if HDI is still low (below the national average) with high poverty (above the national average), then there is a problem in implementing the decentralization policies. Table 1 below shows the comparison of HDI with poverty in Indonesia by province in 2018 (Statistics Indonesia, 2018) .

Based on the data above, it appears that on the island of Sumatra, such as Aceh, South Sumatra, Bengkulu, and Lampung, the decentralization policy has not had a significant effect on increasing HDI (above the national average) and reducing poverty (below the national average). The same thing happened in North Nusa Tenggara (NTB), East Nusa Tenggara (NTT), Central Sulawesi, Southeast Sulawesi, Gorontalo, West Sulawesi, Maluku, West Papua and Papua. However, in some provinces, even though they have achieved HDI above the national average, the poverty rate is still above the national average, as in the Special Region of Yogyakarta (DIY). This shows that the decentralization policy has succeeded in increasing HDI, but it has not been able to reduce poverty below the national average. On the other hand, there are provinces whose poverty
Table 1.

Comparison of Human Development Index and Poverty in Indonesia by Province 2018

\begin{tabular}{|c|c|c|c|}
\hline No. & Province & HDI & Poverty (\%) \\
\hline 1. & Aceh & 71.19 & 15.97 \\
\hline 2. & Sumatera Utara & 71.18 & 9.22 \\
\hline 3. & Sumatera Barat & 71.73 & 6,65 \\
\hline & Riau & 72.44 & 7.39 \\
\hline & Jambi & 70.65 & 7.92 \\
\hline & Sumatera Selatan & 69.39 & 12.80 \\
\hline & Bengkulu & 70.64 & 15.43 \\
\hline & Lampung & 69.02 & 13.14 \\
\hline 9. & Kep. Bangka Belitung & 70.67 & 5.25 \\
\hline 10. & Kepulauan Riau & 74.84 & 6.20 \\
\hline 11. & DKI Jakarta & 80.47 & 3.57 \\
\hline 12. & Jawa Barat & 71.30 & 7.45 \\
\hline 13. & Jawa Tengah & 71.12 & 11.32 \\
\hline 14. & DI Yogyakarta & 79.53 & 12.13 \\
\hline 15. & Jawa Timur & 70.77 & 10.98 \\
\hline 16. & Banten & 71.95 & 5.24 \\
\hline 17. & Bali & 74.77 & 4.01 \\
\hline 18. & Nusa Tenggara Barat & 67.30 & 14.75 \\
\hline 19. & Nusa Tenggara Timur & 64.39 & 21.35 \\
\hline 20. & Kalimantan Barat & 66.98 & 7.77 \\
\hline 21. & Kalimantan Tengah & 70.42 & 5.17 \\
\hline & Kalimantan Selatan & 70.17 & 4.54 \\
\hline 23. & Kalimantan Timur & 75.83 & 6.03 \\
\hline 24. & Kalimantan Utara & 70.56 & 7.09 \\
\hline 25. & Sulawesi Utara & 72.20 & 7.80 \\
\hline & Sulawesi Tengah & 68.88 & 14.01 \\
\hline 27. & Sulawesi Selatan & 70.90 & 9.06 \\
\hline & Sulawesi Tenggara & 70.61 & 11.63 \\
\hline 29. & Gorontalo & 67.71 & 16.81 \\
\hline & Sulawesi Barat & 65.10 & 11.25 \\
\hline & Maluku & 68.87 & 18.12 \\
\hline 32. & Maluku Utara & 67.76 & 6.64 \\
\hline & Papua Barat & 63.74 & 23.01 \\
\hline & Papua & 60.06 & 27.74 \\
\hline & Indonesia & 71.39 & 10.80 \\
\hline
\end{tabular}

Source: Processed from Statistics Indonesia 2018. Note: In 2019 Indonesia's poverty rate is $9.20 \%$

rates are below the national average, but the HDI level is slightly below the national average. Such areas are North Sumatra province, Jambi, Bangka Belitung Islands, West Java, Central Java, East Java, West Kalimantan, Central Kalimantan, South Kalimantan, North Kalimantan, South Sulawesi and North Maluku. This shows that the 
decentralization policy has succeeded in reducing poverty, but it has not yet succeeded in achieving HDI that exceeds the national average. Thus, there are only 8 (eight) provinces that have achieved HDI above the national average and so is the case for poverty rates that are below the national average. These areas are West Sumatra, Riau, Riau Islands, DKI Jakarta, Banten, Bali, East Kalimantan and North Sulawesi.

The above situation can then be grouped according to 4 (four) quadrants, as shown in the matrix 1 below.

Provinces in quadrant I show that the majority of programs have been directed towards increasing HDI and simultaneously reducing poverty. Against such conditions, the eight provinces must continue to improve their various development programs. Then, the provinces in quadrant II show that the formulated program is in line with the increase in HDI, but it has not been able to reduce poverty below the national average. For this province, of course, it must focus on development programs that can reduce poverty. Meanwhile, the provinces in quadrant III show that various programs implemented have not been able to increase HDI to be above the national average, even though they are able to reduce poverty below the national average. Provinces in this quadrant must focus on programs that are able to increase HDI. Finally, provinces in quadrant IV are provinces whose various programs have not been able to increase HDI above the national average and have not been able to reduce poverty. For provinces that are in this quadrant, they must encourage and improve programs that are at the same time

Matrix 1.

Link between Decentralization Policy and HDI and Poverty Levels

\begin{tabular}{|c|c|c|c|}
\hline & & Human Developmer & t Index \\
\hline & & High & Low \\
\hline & High & Quadrant II & Quadrant IV \\
\hline & & 1. Special Region of Yogyakarta (DIY) & 1. Aceh \\
\hline & & & 2. South Sumatera \\
\hline & & & 3. Bengkulu \\
\hline & & & 4. Lampung \\
\hline & & & 5. West Nusa Tenggara \\
\hline & & & 6. East Nusa Tenggara \\
\hline & & & 7. Central Sulawesi \\
\hline & & & 8. Southeast Sulawesi \\
\hline & & & 9. Gorontalo \\
\hline & & & 10. West Sulawesi \\
\hline & & & 11. Maluku \\
\hline Poverty & & & 12. West Papua \\
\hline & & & 13. Papua \\
\hline & Low & Quadrant I & Quadrant III \\
\hline & & 1. West Sumatera & 1. North Sumatera \\
\hline & & 2. Riau & 2. Jambi \\
\hline & & 3. Riau Islands & 3. Bangka Belitung Islands \\
\hline & & 4. Jakarta Capital Special Region (DKI Jakarta) & 4. West Java \\
\hline & & 5. Banten & 5. Central Java \\
\hline & & 6. Bali & 6. East Java \\
\hline & & 7. East Kalimantan & 7. West Kalimantan \\
\hline & & 8. North Sulawesi & 8. Central Kalimantan \\
\hline & & & 9. South Kalimantan \\
\hline & & & 10. North Kalimantan \\
\hline & & & 11. South Sulawesi \\
\hline & & & 12. North Maluku \\
\hline
\end{tabular}

Source: Processed from National Statistic, 2018. 
able to increase HDI and at the same time reduce poverty to below the national average.

\section{Conclusion}

After running for approximately 18 (eighteen) years, the performance of the implementation of decentralization policies has not shown good results. The proof is that there are only 8 (eight) provincial regions out of 34 provincial regions that are truly capable of achieving HDI above the national average and at the same time having poverty levels below the national average. In contrast, there are 13 (thirteen) provincial regions that reach HDI below the national average and at the same time have a poverty rate above the national average.

However, of the 8 (eight) regions considered successful, it still needs to be explored further whether the results achieved are really due to the decentralization policy or other factors. Because it often happens that the regions, especially regencies/municipalities in the provinces, do not direct their programs for poverty reduction. This happens because there is an assumption that poverty reduction is the responsibility of the central government. In addition, there is also an assumption that in addition to the affairs of the central government, poverty is a matter for international institutions. Thus, it often happens that between regional programs, the central government, and/or international institutions in the regions are not interlocked. Thus, it is not surprising that the Millennium Development Goals (MDGs) program, even though it has been running for 15 years in Indonesia, has not been successful. This is indicated by the continued program, namely Sustainable Development Goals (SDGs).

Global changes can also be a cause of poverty reduction in one region. At the farmer level, for example, due to the emergence of farmer-hub start-ups, relations between farmers and buyers can occur immediately without going through third parties, such as collectors, small traders to large traders (toke). The direct relationship between farmers and buyers, even in other parts of the world, can increase farmers' incomes, due to farmers' higher agricultural prices compared to before. Thus, regional programs must also be synergized with the central government program and with the global change in question.

\section{References}

Adams, D. (2002). Poverty-A Precarious public policy idea. Australian Journal of Public Administration, 61(4), 89-98. doi:10.1111/1467-8500.00305.

Amal, I., \& Pratikno. (1996, August 2). Decentralization in Indonesia between social empowerment and local revenue (PAD) increase. Presented on National Conference, Implementation of Decentralization at Five Years Development Term (Pelita) VII Retrospect and Prospect in Increasing of Investation, Commerce and Local Revenue, pp. 1-15.

Bhagwati, J. N. (1988). Poverty and public policy. World Development, 16(5), 539-555.

Bird, R., \& Rodriguez, E. R. (1999). Decentralization and poverty alleviation, international experience and the case of the Philippines. Pubilc Administration and Development, 19, 299-319. doi:10.1002/(SICI)1099-162X

Cresswell, J.W.(2009). Research design: Qualitative, quantitative, and mixed methods approaches. Los Angeles: Sage Publications.

Denzin , N. K., \& Lincoln, Y. S. (2005). Introduction: The discipline and practice of qualitative research. In Y. \&. Denzin, The Sage Handbook of Qualitative Research (p. 3). Thousand Oaks: Sage Publication.

Haboddin, M. (2017). Desentralisasi dan kemiskinan. Jejaring Administrasi Publik, 9(1), 1046-1055. Retrieved from http:// journal.unair.ac.id/download-fullpapersadmpfb5934e8a4full.pdf 
Hafid, A. (2018, March 22-23). To develop of morowali blessing by building of human resources. Presented on Annual Conference of Asian Association for Public Administration, pp. 1-16.

Heltberg, R. (2009). Malnutrition, poverty, and economic growth. Health Economic, 18, 77 88. doi:10.1002/hec.1462.

Hutahaean, M. (2006). Penataan Kelembagaan, perubahan paradigma, dan pilihan kebijakan sebagai langkah strategis menanggulangi kemiskinan: Perspektif administrasi publik. Jurnak Kebijakan dan Administrasi Publik, 10(1), 35-50. doi:10.22146/jkap.8317.

Jia, J., Guo, Q., \& Zhang, J. (2014). Fiscal decentralization and local expenditure policy in China. China Economic Review, 28, 107-122.

Jones, T. (2002, December). Policy coherence, global environmental. International Environmental Agreements: Politics, Law and Economics, 2(4), 389-401. doi:10.1023/A:1021319804455

KPPOD. (2011). Kinerja daerah baru jeblok. South Jakarta, DKI Jakarta, Indonesia. Retrieved from https://www.kppod.org/berita/ view?id=130

Kuncoro, M. (2004). Otonomi dan pembangunan daerah: Reformasi, perencanaan strategi dan peluang. Jakarta: Erlangga.

Lisna, V., Sinaga, B. M., Firdaus, M., \& Sutomo, S. (2013). Impact of fiscal capacity on poverty reduction: A policy simulation analysis. Jurnal Ekonomi dan Pembangunan Indonesia, 14(1), 1 - 26. doi:10.21002/jepi. v14i1.433.

Rudzali , A., \& Sudarlan. (2016). Dampak otonomi daerah terhadap pendapatan per kapita dan pengentasan kemiskinan di Kalimantan Timur. Jurnal Eksis, 12(1), 3274-3281. doi:10.33087/eksis

Schneider, A. (2003, September). Decentralization: Conceptualization and measurement. Studies in Comparative International Development, 38(3), 32-56. doi:10.1007/BF02686198

Statistics Indonesia. (2018). Data and information of poverty in district/municipality. Jakarta: Statistics Indonesia.

Statistics Indonesia. (2018). Human development index. Jakarta: Statistics Indonesia.

Stumpf, K. S. (2002). Does government decentralization increase policy innovation? Journal of Public Economic Theory, 4(2), 207-241.

UNDP. (1999, October). Decentralization: A sampling of definitions. Working paper prepared in connection with the Joint UNDPGovernment of Germany evaluation of the UNDP role in decentralization and local governance, p. 28.

Vazquez, J. M., \& Mcnab, R. M. (2003, February). Fiscal decentralization and economic growth. World Development, 31(9), 1597-1616. doi:10.1016/S0305-750X(03)00109-8 